Ekonomia - Wroclaw Economic Review 23/1 (2017)

Acta Universitatis Wratislaviensis

No 3754

DOI: 10.19195/2084-4093.23.1.6

Małgorzata Niklewicz-Pijaczyńska Uniwersytet Wrocławski

malgorzata.niklewicz-pijaczynska@uwr.edu.pl

Aldona Sobiecka

Polski Związek Głuchych

aldona.l@wp.pl

\title{
Aktywność wynalazcza w sektorze technologii związanej z niedosłuchem w konfrontacji z bodźcami popytowymi
}

JEL Classification: I1, I15, 031, 035

Keywords: patents, innovations, disability, hearing impairment

\section{Abstract}

Inventive activity in the technology sector related with hearing loss when confronted with demand stimulus

The issue of the article focuses on the demand and supply innovation incentives aimed at people with varying degrees of hearing loss. The aim of this publication is to confront actual inventive activity representing the supply side with expectations of their users who create demand-side innovative incentives. Thus, for the purposes of this article will be used two research methods. Inventive activity will be analyzed using the patent metrics tools. Its assessment and identification of users expectations (on the example of hearing aids) will be made based on results of questionnaires.

\section{Wprowadzenie}

Jednym z priorytetowych wyzwań stojących przed współczesnymi gospodarkami wiedzy jest takie wykorzystanie potencjału intelektualnego społeczeństw i kreowanych przez nie rozwiązań technicznych i technologicznych, aby w znaczący i niedyskryminujący sposób wpłynęly na poprawę jakości życia, w tym uwarunkowanej stanem zdrowia. Według terminologii z zakresu nauk medycznych tak rozumiana jakość życia ujmowana jest w sposób holistyczny, bynajmniej nie jako brak choroby lecz stan pełnego psychicznego i społecznego dobrego samopoczucia 
(Schipper et al., 1996). Tym samym mianem jakości życia określa się zespół czynników o charakterze fizycznym, psychicznym i społecznym wpływający na „spostrzeganie przez jednostkę jej pozycji w życiu w kontekście kultury i systemów wartości w jakich żyje oraz w relacji do jej celów, oczekiwań, standardów i zainteresowań” (WHO, 1993). Czynniki, które sumują się na tak rozumianą jakość życia, to stan zdrowia fizycznego i psychicznego, stopień niezależności, relacje z innymi ludźmi oraz czynniki środowiskowe (Saxena, Orley, 1997). Zdecydowanie grupą, której jakość funkcjonowania nadal pozostaje na znacząco niższym w porównaniu z osobami zdrowymi poziomie, są osoby z różnym stopniem niepełnosprawności, w tym związanymi z zakłóceniem szeroko rozumianych funkcji otolaryngologicznych. Współcześnie, zaburzenia o charakterze sensorycznym, w tym niedosłuch, należą do coraz powszechniejszego problemu wywołującego poważne konsekwencje nie tylko w odniesieniu do jednostki nim dotkniętej, lecz także w skali makro, jako realnej straty gospodarczej związanej z nieefektywnym wykorzystaniem potencjału ludzkiego. Przy czym jakość życia oceniana jest w tym przypadku w sposób subiektywny przez pacjenta lub jego opiekunów, uwzględniających fizyczny, psychiczny i społecznego aspekt funkcjonowania w określonym kontekście.

Pojawia się zatem pytanie, czy współczesna technologia, proces komercjalizacji wynalazków, mechanizmy kreowania innowacji faktycznie wpływają na poprawę funkcjonowania osób niepełnosprawnych przy uwzględnieniu ich potrzeb zawodowych, kulturalnych, rodzinnych, zdrowotnych, oraz w jakim stopniu podmioty aktywne w tym sektorze dostrzegają te potrzeby, realizują je i aktywnie tworzą kolejne wynalazki, których rolą jest ostateczne podniesienie jakości społecznej egzystencji. Wynalazki w obszarze zaburzeń słuchu powinny mieć bowiem na celu takie oddziaływanie techniczne, które pozwoliłoby na poprawę jakości funkcjonowania przez usunięcie lub zminimalizowanie trudności, takich jak porozumiewanie się w miejscach publicznych i sferze prywatnej, problemów wynikających z użytkowania dóbr publicznych (komunikacji transportowej), aktywizacją naukową (czynny udział w konferencjach) oraz zawodową.

Celem artykułu jest konfrontacja realnej aktywności wynalazczej podmiotów zaangażowanych w tworzenie rozwiązań technologicznych użytecznych dla pacjentów z różnym stopniem upośledzenia słuchu, z ich subiektywnymi oczekiwaniami względem produktów i usług mogących poprawić ich jakość życia. Cel ten zostanie zrealizowany przez przeprowadzenie badań własnych na dwóch płaszczyznach będących odzwierciedleniem popytowych i podażowych bodźców tworzenia innowacji przełomowych w tym obszarze. Podwójna perspektywa badawcza wymagać będzie zróżnicowanej metodologii. Aktywność wynalazcza zostanie zanalizowana przy użyciu narzędzi patentometrii. Natomiast popytowe bodźce innowacyjne zbadane zostaną przy wykorzystaniu autorskiego kwestionariusza adresowanego do osób z różnym stopniem niedosłuchu. 


\section{Wpływ wad słuchu na jakość życia pacjentów niedosłyszących i głuchych}

Światowa Organizacja Zdrowia podaje, że problemy z prawidłowym słyszeniem odczuwa już ponad 360 milionów osób na świecie, z czego 32 miliony stanowią dzieci, a 1/3 tej grupy osoby po 65 roku życia (www.who.int/pbd/deafness/news/ IECD/en/index1.html, 2013). Tymczasem człowiek za pomocą słuchu odbiera $8-10 \%$ informacji z otaczającego go świata. Ubytek słuchu stanowi poważny problem dla całego otoczenia osoby niedosłyszącej — rodziny, współpracowników i przyjaciół. Częste nieporozumienia, ciągłe powtarzanie, stają się coraz bardziej męczące i frustrujące. Większość ludzi dotkniętych niedosłuchem nie tylko słyszy „ciszej”, lecz także zmniejsza się radykalnie ich zdolność do rozumienia mowy, nawet jeżeli jest ona dość głośna. Osoby z ubytkiem słuchu bardzo często słyszą, że ktoś do nich mówi, ale nie rozumieją wypowiedzi. Wszelkie dźwięki dodatkowe (inna mowa, hałas uliczny itp.) w znaczący sposób zaburzają rozumienie mowy, która jest zagłuszana przez te sygnały. Każdy z nas ma pewne problemy ze zrozumiałością mowy w hałasie — pamiętajmy, że w przypadku ubytku słuchu rozumienie mowy jest nieporównywalnie bardziej utrudnione. Wiele osób dotkniętych ubytkiem słuchu czuje zakłopotanie z powodu niedosłuchu. Osoby te nierzadko wstydzą się swoich problemów ze słyszeniem i starają się udawać, że mają normalny słuch. Upośledzenie jednego z głównych organów zmysłowych zakłócające percepcje dźwiękową staje się dla tej grupy osób przeszkodą w funkcjonowaniu na następujących płaszczyznach:

- poznawania przedmiotów i zjawisk (brak odbioru dźwięków z otoczenia);

— realizacji działań praktycznych (brak oceny funkcjonowania urządzeń mechanicznych);

— doświadczania przeżyć estetycznych (muzyka), orientacji przestrzennej;

- poruszania się (brak odbioru dźwięków ostrzegawczych i zachowania równowagi w ciemności).

Do utrudnień tych dodać należy także trudności w komunikowaniu, które stanowią dominujący problem życia codziennego osób niedosłyszących i głuchych. Istotnym problemem staje się także społeczny odbiór osób z uszkodzeniem słuchu. Osoby z uszkodzonym narządem słuchu mają zaburzoną percepcje dźwięków, często posługują się nieprecyzyjnymi określeniami. Jednak znacznie większe zagrożenie od nieznajomości terminologii stanowią fałszywe i krzywdzące mity społeczne, które budują błędny i uproszczony obraz niedosłyszących i głuchych. Osoby słyszące nie są w stanie wyobrazić sobie, jak żyje się w świecie ciszy, ponieważ postrzegają głuchotę przez pryzmat ewentualnej możliwości utraty dostępu do świata dźwięków. Wyobrażają sobie, jak mogłyby się czuć, gdyby pozbawiono je słuchu i w oparciu o to wyobrażenie kreślą uogólniony obraz osoby dotkniętej uszkodzeniem słuchu: wyizolowanej, zdezorientowanej, niekomunikatywnej, odciętej od 
świata i ludzi. Ponadto, spotykając osoby z wadą słuchu, słyszący często przypisują im inny rodzaj niepełnosprawności - najczęściej upośledzenie umysłowe lub wadę wymowy. Bariera stereotypów oddzielająca świat dźwięków od świata ciszy sprawia, że osoba dotknięta tą niepełnosprawnością zostaje w pewnym stopniu wyizolowana ze społeczeństwa. Pomimo że utrata jednego ze zmysłów nie pozbawia człowieka jego ludzkiej natury, a postawy społeczne wobec niedosłyszących i głuchych ewoluowały w pozytywnym kierunku (przechodząc przez fazy dyskryminacji, izolacji i separacji w kierunku integracji), w praktyce niewiele się zmieniło jeśli chodzi o postrzeganie głuchych przez słyszących.

\section{Aktywność wynalazcza w sektorze związanym z niepełnosprawnością słuchową, mierzona metodą patentometrii na podstawie danych Urzędu Patentowego RP}

Jednym ze społecznych celów kreowania nowych rozwiązań technologicznych jest pozytywne wpływanie na poziom i jakość życia ich użytkowników. Cel ten wynika m.in. z uzasadnienia ochrony wynalazków w postaci czasowego monopolu patentowego - społeczeństwo godzi się na przyznanie wynalazcy wyłączności, aby móc w pełni korzystać z efektów podejmowanego przez niego wysiłku twórczego. Ale potwierdzenie społecznej funkcji wynalazku znajdujemy też w orzecznictwie odnoszącym się do cech obligatoryjnych wynalazku, w tym jego „techniczności”. Zgodnie z wykładnią wymóg ten spełniają

rozwiązania, które dotyczą jednej z dziedzin techniki jako sfery działalności ludzkiej, w której empirycznie stosowane nauki przyrodnicze pozwalają na stworzenie środków i sposobów, przy pomocy których człowiek może lepiej oddziaływać na materię i przez to zaspokajać swoje potrzeby. W konsekwencji uznaje się, że sfera techniki nie wykracza poza domenę nauk przyrodniczych, a przede wszystkim mechaniki, fizyki i chemii, zaś jej przedmiotem jest wykorzystanie materii nieożywionej lub ożywionej. W sferze techniki nie mieszczą się zatem rozwiązania, których przedmiotem są pomysły o charakterze abstrakcyjno-myślowym, w tym organizacyjnym, gdyż rozwiązują one problemy intelektualne lub organizacyjne. Nie zwiększają zaś arsenału środków technicznego oddziaływania na materię. Realizacja tych pomysłów może bowiem nastąpić bez takiego oddziaływania i wymaga wyłącznie weryfikacji logicznej - a nie eksperymentalnej, jak w przypadku nauk przyrodniczych (wyrok z dnia 25 sierpnia 2010 r., sygn. akt VI SA/Wa 853/10, LEX nr 759763).

Aktywność w obszarze tzw. innowacji przełomowych (wynalazków) związana z rozwiązaniami technologicznymi przeznaczonymi dla osób z niedosłuchem można zmierzyć, wykorzystując dokumentację patentową według klasyfikacji międzynarodowej (MKP) zgromadzoną w dziale $\mathrm{H}$ związaną $\mathrm{z}$ eletrotechniką i A z podstawowymi potrzebami ludzkimi. Analiza objęła w sumie 319 zgłoszeń patentowych w zakresie czasowym od 1996 roku do stanu obecnego. Jednak spośród ogólnej liczby znacząca część należąca do podmiotów zagranicznych uznana została przez urząd patentowy za nieważne z powodu braku tłumaczenia na język 
polski. W konsekwencji są to rozwiązania chronione w ramach europejskiego systemu patentowego, ale niestanowiące praw wyłącznych na terytorium RP.

W całym analizowanym okresie jedynie 17 zgłoszeń doczekało się przyznania ochrony (12) lub jest $\mathrm{w}$ trakcie weryfikacji patentowej (5). Natomiast $\mathrm{w}$ dziesięciu przypadkach przyznane prawa wyłączne wygasły z powodów formalnych, czyli niedokonania opłaty za dalszy okres ochronny. Może to wskazywać na niską wartość komercyjną wynalazku lub jego przedawnienie technologiczne, skutkujące nieopłacalnością ponoszenia dalszych kosztów ochrony (rysunek 1).

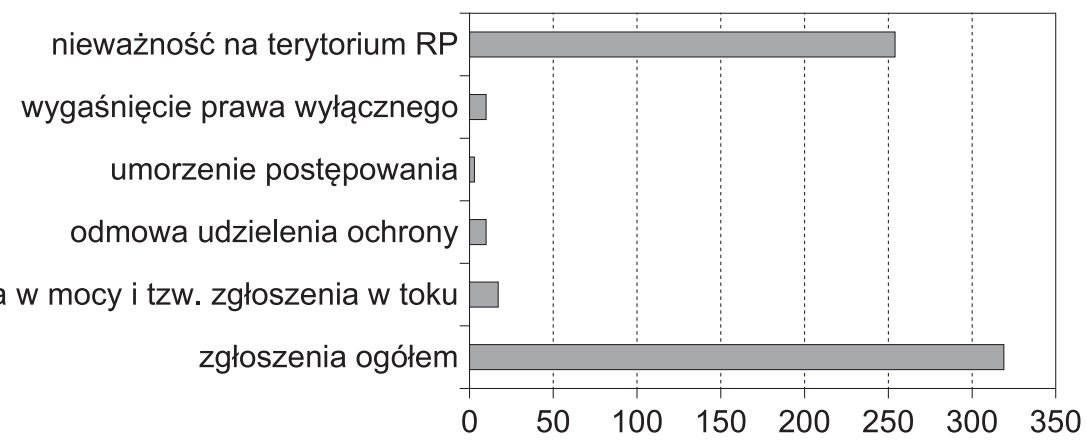

Rysunek 1. Liczba zgłoszeń wynalazków z obszaru niedosłuchu zarejestrowanych w UPRP w latach 1996-2016

Źródło: opracowanie własne na podstawie danych UPRP.

W ogólnej liczbie zgłoszeń dokonanych w UPRP dominującą pozycję zajęły te dokonane przez podmioty zagraniczne. Natomiast w grupie patentów i zgłoszeń w tzw. toku to podmioty krajowe zyskały miano lidera.

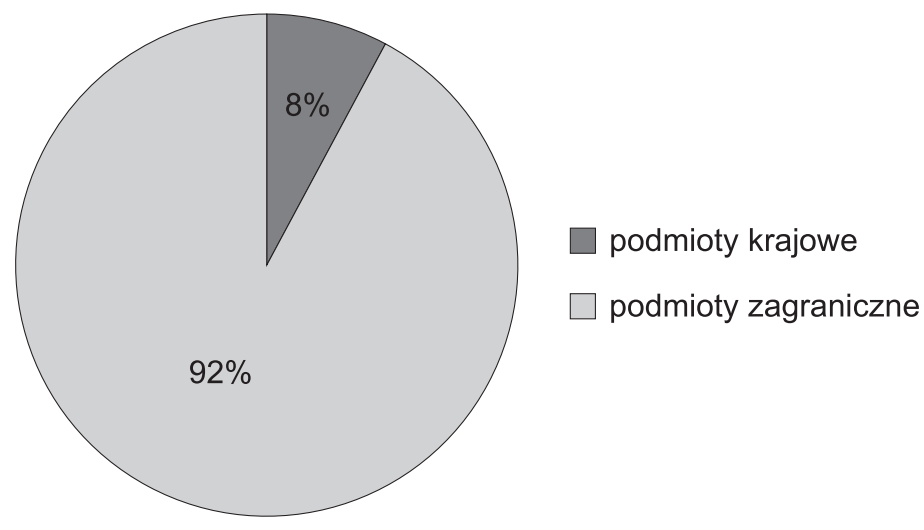

Rysunek 2. Zgłoszenia wynalazków według podmiotów krajowych i zagranicznych w latach 1996-2016

Źródło: opracowanie własne na podstawie danych UPRP. 
Analiza struktury zgłoszeń zagranicznych wykazała, że podmiotami najbardziej aktywnymi ze względu na wynalazki są w tym przypadku przedsiębiorstwa, w dalszej zaś kolejności osoby fizyczne. Natomiast tylko w jednym przypadku uprawnionym $\mathrm{z}$ tytułu patentu była jednostka badawcza. Odmiennie powyższa struktura kształtowała się w odniesieniu do podmiotów krajowych, tutaj zdecydowany prymat wiodły rozwiązania jednostek badawczych i uczelni wyższych. Może to wskazywać, że polskie firmy raczej wykorzystują wynalazki opracowane w laboratoriach i w ramach prac badawczo-rozwojowych, niż decydują się wykreować własne. Wskazuje również na ogromną rolę ośrodków badawczych w tworzeniu innowacji poprawiających jakość funkcjonowania osób niedosłyszących (rysunek 3).

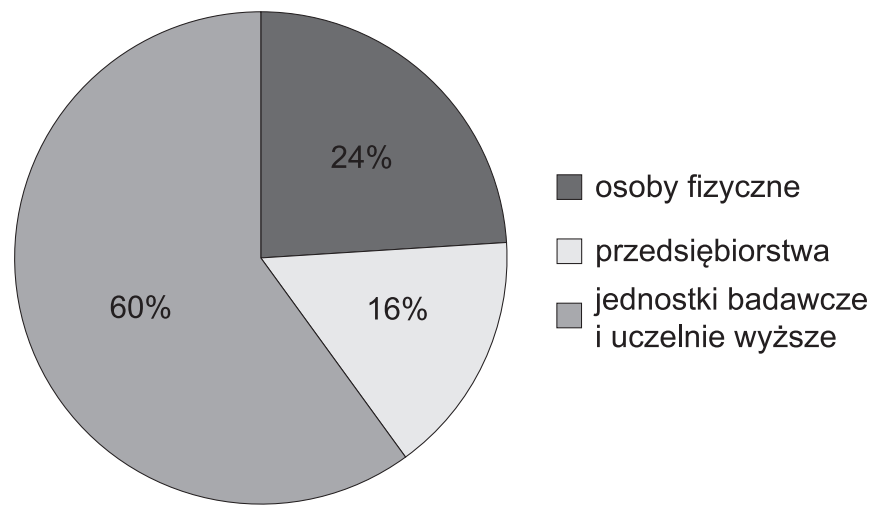

Rysunek 3. Zgłoszenia wynalazków według rodzaju podmiotów rodzaju podmiotów krajowych w latach 1996-2016

Źródło: opracowanie własne na podstawie danych UPRP.

Objęte ochroną patentową wynalazki w przeważającej części dotyczyły wzmocnienia funkcjonalności aparatów słuchowych oraz efektywności badań audiometrycznych, ale zdarzały się rozwiązania mające za zadanie poprawę ogólnej życiowej jakości funkcjonowania osób niedosłyszących. Warte uwagi są rozwiązania dotyczące protezowania kosteczek słuchowych, proponowane zarówno przez podmioty krajowe, jak i zagraniczne, szeroko wykorzystywane w otochirurgii. Pełne zestawienie wynalazków zgłoszonych do opatentowania w UPRP prezentuje poniższa tabela.

Tabela 1. Zestawienie wynalazków opatentowanych w UPRP w latach 1996-2016

\begin{tabular}{l|l}
\hline AT & $\begin{array}{l}\text { ulepszony aparat słuchowy o bezpośrednim działaniu na ucho środkowe i powiązany } \\
\text { sposób jego instalacji }\end{array}$ \\
\hline US & $\begin{array}{l}\text { sposób sterowania wzmocnieniem dźwięku z wykorzystaniem detekcji zdarzeń } \\
\text { słuchowych opartej na głośności }\end{array}$ \\
\hline DE & sposób dopasowywania aparatów słuchowych \\
\hline
\end{tabular}




\begin{tabular}{l|l}
\hline PL & proteza kosteczek słuchowych \\
\hline PL & proteza kosteczek słuchowych \\
\hline PL & aparat słuchowy \\
\hline DE & aparat słuchowy \\
\hline NL & aparat słuchowy \\
\hline PL & sposób i układ do badań przesiewowych słuchu \\
\hline DE & sposób określenia indywidualnej sprawności słuchu \\
\hline AT & proteza kosteczka słuchowej zastępująca kowadełko \\
\hline PL & $\begin{array}{l}\text { sposób prowadzenia treningu słuchowo-wzrokowego zwłaszcza u osób z zaburzeniami } \\
\text { lateralnymi }\end{array}$ \\
\hline
\end{tabular}

Źródło: opracowanie własne na podstawie danych UPRP.

Analiza wyników wywiadu kwestionariuszowego

W celu identyfikacji oczekiwań pacjentów wobec użytkowanych przez nich aparatów słuchowych (a zarazem zdefiniowanie popytowych bodźców innowacyjnych) przeprowadzono badania pilotażowe wśród pacjentów Polskiego Związku Głuchych we Wrocławiu. Badania przeprowadzone w okresie kwiecień-maj 2016 oparto na autorskim kwestionariuszu składającym się 22 pytań. Dominującą wśród 14 respondentów grupą byli pacjenci w wieku 25-30 lat oraz po 35 roku życia, w zdecydowanej większości mający wykształcenie wyższe. W badanej grupie przeważały kobiety. Natomiast dochód respondentów kształtował się w granicach 1800-3000 zł netto na osobę (osiem wskazań) oraz na poziomie do 1800 i powyżej 3000 zł netto na osobę (odpowiednio po trzy wskazania). Zdecydowanie przeważającą grupą były osoby, u których problemy ze słuchem pojawiły się $\mathrm{w}$ okresie dzieciństwa lub tuż po urodzeniu, jedynie u trzech dały się zauważyć dopiero po 18 roku życia i u żadnego z pacjentów nie występował z innymi chorobami współistniejącymi. Jednocześnie wszyscy respondenci okazali się osobami czynnymi zawodowo. Okazało się, że ośmiu z nich użytkuje aparaty słuchowe długookresowo — powyżej trzech lat i tyleż samo, bardzo intensywnie — przez cały dzień. Jednocześnie 14\% ankietowanych zakłada je, jedynie gdy istnieje konieczność załatwienia ważnych spraw (np. urzędowych) lub wyłącznie w pracy. Najpopularniejszą marką okazały się aparaty firmy Phonak, tylko jednostkowo wymieniono inne marki — Siemens. Oticon czy Interton (rysunek 4). 


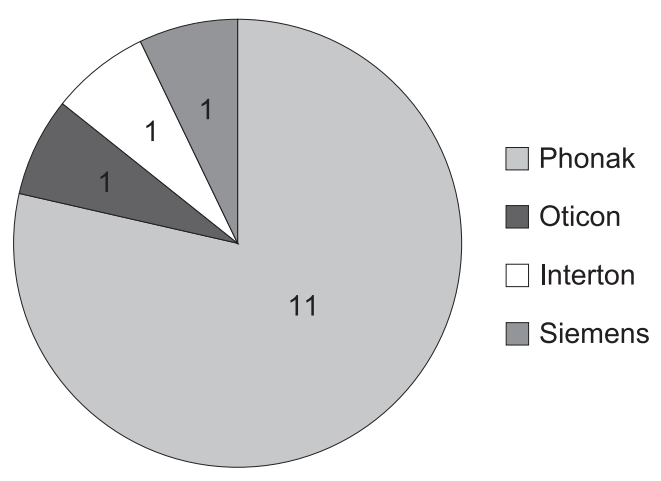

Rysunek 4. Marki aparatów słuchowych użytkowane przez respondentów

Źródło: opracowanie własne.

Badania pokazały jednocześnie, że ankietowani nie dokonują doboru aparatu samodzielnie, powierzają tę decyzję osobom sprzedającym urządzenie, ufając, że dokonają najlepszego dla nich wyboru. Jedynie czworo ankietowanych zdecydowało się na wcześniejsze, testowe wypożyczenie aparatu słuchowego w celu zoptymalizowania ostatecznego wyboru, co więcej, ostatecznie i tak decydowały się na nabycie tej marki, którą testowali. Tylko jedna osoba wypożyczyła aparaty dwóch firm. Respondenci zapytani następnie, czy aparaty słuchowe poprawily ich komfort funkcjonowania w codziennych, społecznych sytuacjach, przyznawali, że zdecydowanie oraz raczej tak (po pięć odpowiedzi). Także w kolejnym pytaniu, o poprawę funkcjonowania w życiu zawodowym, udzielone odpowiedzi były przeważająco pozytywne. Następnie respondenci odpowiedzieli na serię pytań dotyczących bezpośrednio efektywności użytkowanych przez nich urządzeń. Były one powiązane z tymi obszarami, które potencjalnie wymagają modyfikacji, tym samym wymuszając wprowadzanie innowacji. Zapytani, czy aparat wyeliminował problemy z rozumieniem mowy, zapytani udzielali odpowiedzi, które rozłożyły się dość proporcjonalnie.

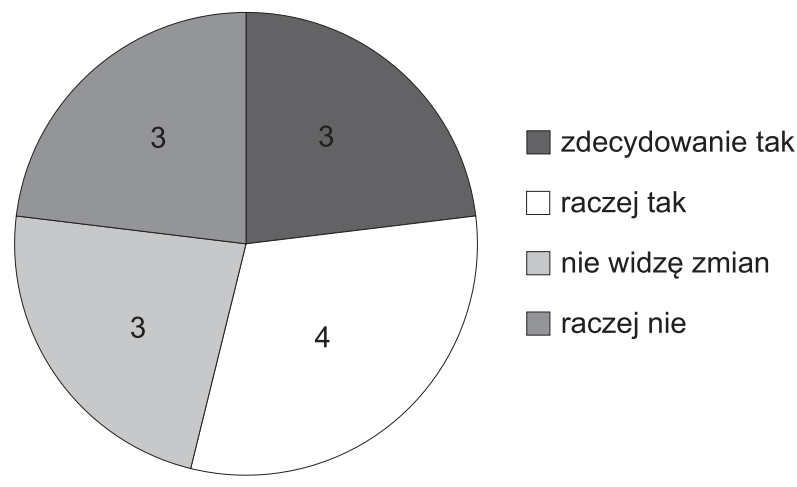

Rysunek 5. Odpowiedzi na pytanie, czy aparat wyeliminował problemy z rozumieniem mowy Źródło: opracowanie własne. 
Podobnie było w przypadku odpowiedzi na pytanie, czy aparat słuchowy wyeliminował kłopoty ze złą słyszalnością dźwięków.

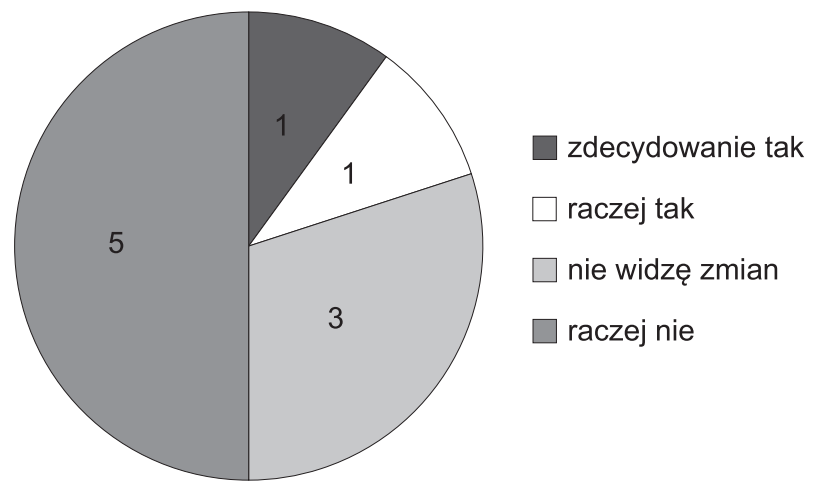

Rysunek 6. Odpowiedzi na pytanie, czy aparat słuchowy wyeliminował kłopoty ze złą słyszalnością dźwięków

Źródło: opracowanie własne.

Zdecydowanie nieskuteczne okazały się natomiast aparaty w eliminowaniu problemów występowania tzw. szumów usznych. Połowa ankietowanych odpowiedziała, iż raczej nie, $30 \%$ nie widzi żadnych zmian w tym obszarze. Dużo lepiej urządzenia te radzą sobie z poprawą w zakresie identyfikacji kierunków i źródeł dźwięków. W tym przypadku odpowiedzi były przeważnie twierdzące.

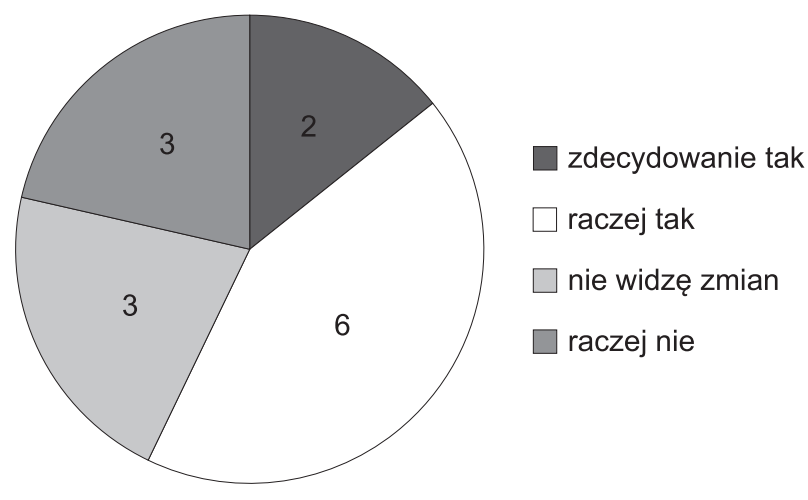

Rysunek 7. Odpowiedzi na pytanie, czy aparat słuchowy wyeliminował problem ,szumów usznych"

Źródło: opracowanie własne.

Warto zauważyć, iż w celu odczucia poprawy komfortu słyszenia, niezbędne jest właściwe indywidualne ustawienie aparatów słuchowych. Jest to problem niezwykle złożony, ponieważ podstawą programowania odpowiedniej częstotliwości, tonacji dźwięków nie są bynajmniej obiektywne badania audiometryczne, lecz su- 
biektywne doznania słuchowe sygnalizowane przez pacjentów. Odczucia te zaś są zróżnicowane w zależności od warunków fizycznych i otoczenia, w którym dokonuje się ustawień, czy też stanu psychicznego pacjentów. Nie dziwi więc rozkład odpowiedzi na pytanie, czy występowały problemy z właściwym ustawieniem aparatów.

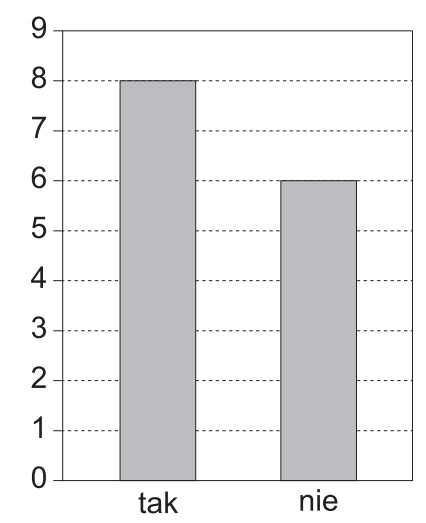

Rysunek 8. Odpowiedź na pytanie: Czy występowały problemy z właściwym ustawieniem aparatów słuchowych

Źródło: opracowanie własne.

Zapytani z kolei o czynniki wpływające na dyskomfort w użytkowaniu aparatów słuchowych respondenci wymienili następujące czynniki (według częstotliwości wskazań):

— nasilenie nieprzyjemnych dźwięków z otoczenia,

— wielkość aparatów,

— świsty, piski,

— wrażenie ,zatkanego ucha”.

Jeśli chodzi o udoskonalenia, które $\mathrm{w}$ ich subiektywnym odczuciu poprawiłyby komfort użytkowania aparatów, zdecydowanie byłaby to modyfikacja w zakresie lepszego rozumienia mowy.

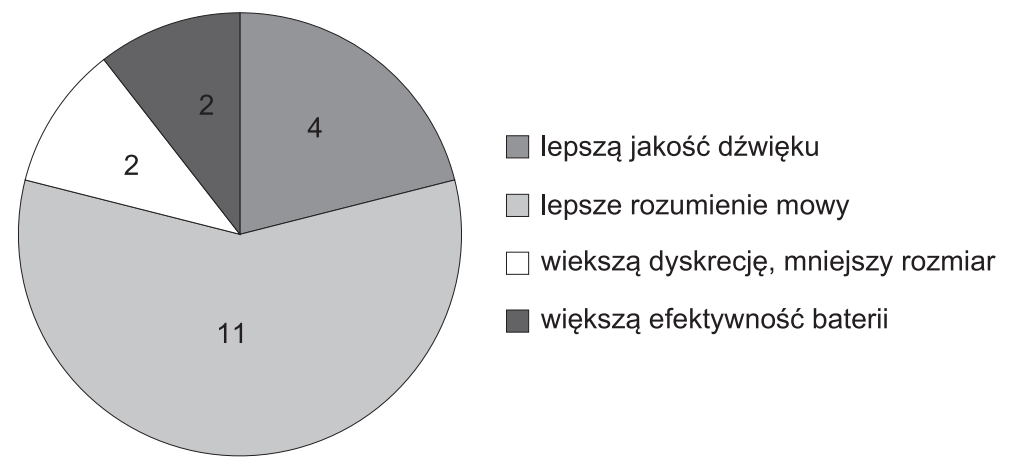

Rysunek 9. Odpowiedź na pytanie: Jakie udoskonalenia chcieliby Państwo wprowadzić w swoich aparatach słuchowych

Źródło: opracowanie własne.

Ekonomia - Wroclaw Economic Review 23/1 (2017)

(C) for this edition by CNS 
$\mathrm{Na}$ koniec zadano respondentom dwa pytania. Pierwsze dotyczyło kwestii, czy korzystają oni z innych urządzeń wspierających słyszenie. W tym przypadku odpowiedzi twierdzące były sporadyczne i jeśli już się pojawiały, to wymieniano tu systemy komunikacyjne, specjalne telefony komórkowe, urządzenia sygnalizacyjne.

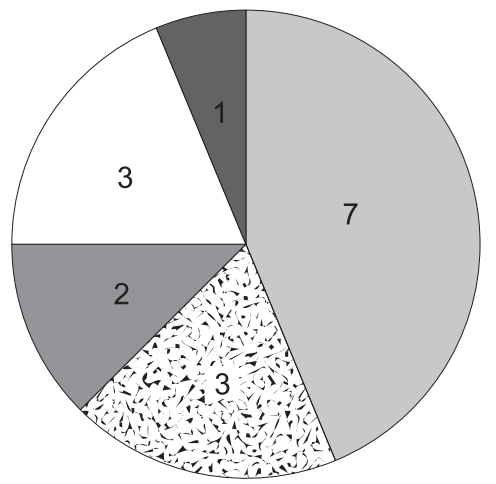

$\square$ nie

๑ tak, urządzeń sygnalizacyjnych

tak, systemów komunikacyjnych

tak, telefonu komórkowego

tak, systemów radiowych

Rysunek 10. Odpowiedź na pytanie: Czy korzystają Państwo z urządzeń wspierających słyszenie

Źródło: opracowanie własne.

Natomiast zdecydowana większość nie wykorzystuje żadnych innych urządzeń niż aparaty słuchowe. Przyczyny oczywiście mogą być zróżnicowane brak wiedzy w tym obszarze, niedostępność urządzeń, brak środków finansowych na ich nabycie. O ile wszystkie te czynniki mogą mieć realne znaczenie, o tyle nieposiadanie informacji na ten temat może być podstawowym. Wniosek taki wynika pośrednio z odpowiedzi na ostatnie kwestionariuszowe pytanie. Zapytani o to, z jakiego rodzaju urządzeń wspierania słuchu chcieliby korzystać w codziennym życiu (w tym nieistniejących na rynku), w większości nie potrafili podać żadnej odpowiedzi. W pojedynczych wskazaniach wymieniono urządzenie pomagające $\mathrm{w}$ odbiorze telewizji, wykorzystywania pomocy konferencyjnych oraz specjalnych wzmacniaczy dźwięku w domofonach i telefonach.

\section{Zakończenie}

Wszystkie osoby z uszkodzonym słuchem doświadczają codziennych trudności w takim samym stopniu. W celu poprawy warunków egzystencji wszystkie te osoby mogą korzystać z różnych urządzeń wspomagających. Przyrządy te są jednak $\mathrm{w}$ dalszym ciągu niedoskonałe. Zarówno aparaty słuchowe, jak i implanty ślimakowe oraz pniowe są protezami i w związku $\mathrm{z}$ tym żadne $\mathrm{z}$ tych urządzeń nie zastępuje normalnego słyszenia ani też nie kompensuje w pełni ubytku słuchu. Protezy mogą wzmacniać słuch tylko $\mathrm{w}$ takim zakresie, na jaki pozwalają resztki słuchu. Tymczasem zaburzeń w zakresie porozumiewania się, a w konsekwencji alienacji 
psychicznej, społecznej, edukacyjnej i zawodowej nie sposób dziś bagatelizować, ponieważ dotyczyć ona będzie coraz większego odsetka społeczeństw i co więcej, także osób coraz młodszych. Niestety intensywność kreowania rozwiązań w tym obszarze wydaje się nadal znikoma. W badanym okresie, długim, bo aż dwudziestoletnim, jedynie siedemnaście wynalazków z obszaru niedosłuchu spełniło wymogi formalne i merytoryczne. Co istotne, badania dokumentacji patentowej, ocenianej przy uwzględnieniu kryterium geograficznego, pokazują pewną dwoistość podmiotową — w przypadku rozwiązań krajowych dominującą pozycję zajmują jednostki badawczo-rozwojowe w odniesieniu do wynalazków obcych natomiast przedsiębiorstwa. Jednocześnie głównym przedmiotem zainteresowania niezmiennie pozostają przede wszystkim rozwiązania dotyczące poprawy efektywności aparatów słuchowych. Biorąc pod uwagę zróżnicowanie potrzeb związanych ze społecznym funkcjonowaniem osób niedosłyszących, koncentracja aktywności wynalazczej na tak wąskim polu wydaje się niewystarczająca. Co więcej, analiza dokumentacji zgłoszeń patentowych oraz badania ankietowe wskazują, że strona popytowa i podażowa innowacji przeznaczonych dla osób niedosłyszących zazębiają się w pewnych płaszczyznach, przede wszystkim tam, gdzie celem jest poprawa komunikowania się z użyciem aparatów słuchowych. Analiza odpowiedzi respondentów, której przedmiotem była ocena funkcjonalności aparatów słuchowych i potencjalnych innowacji produktowych wykazała jednak, że bodźce popytowe w tej materii są bardzo słabe. Osoby niedosłyszące przy wyborze aparatów cechuje wysoki stopień niesamodzielności, kierowanie się przyzwyczajeniem oraz opinią osób postronnych. I to mimo iż dobór aparatu kompatybilnego z pacjentem jest problemem wysoce indywidualnym. Nieposiadanie stosownej podstawowej wiedzy, niechęć do weryfikacji informacji, zagubienie to kolejne czynniki wpływające na osłabienie popytowych bodźców innowacyjnych. Charakterystyczny brak konkretnych sugestii co do kierunków rozwoju innowacji ogólnie, które mają im przede wszystkim służyć, nie oznacza jednak całkowitego braku oczekiwań. Można o nich wywnioskować pośrednio z odpowiedzi oceniających wykorzystywane już aparaty. Wyniki w tym obszarze pokazują, że pożądane będą wszelkie modyfikacje poprawiające przede wszystkim zdolność rozumienia mowy, określenia źródeł i kierunków dźwięków oraz eliminacją nieprzyjemnych, wzmacnianych przez aparaty hałasów różnego typu, które dodatkowo wywołują stres i dezorientację w otoczeniu. Pytanie, czy sygnały te warto uwzględnić przy kolejnych wprowadzanych innowacjach, jest pytaniem retorycznym, ponieważ zapytani, czy aparat realnie wpłynął na poprawę samopoczucia i postrzeganie siebie, $43 \%$ ankietowanych odpowiedziało, że zdecydowanie tak.

Reasumując, warto mieć na względzie, że osoby głuche i niedosłyszące są wystarczająco sprawne intelektualnie i fizycznie, aby samodzielnie zadbać o swoje sprawy. Potrzebują jedynie od słyszącego społeczeństwa wyjścia naprzeciw we wzajemnej komunikacji i zrozumieniu swoich potrzeb. Temu zaś powinna służyć podejmowana w tym obszarze aktywność wynalazcza. 


\section{Bibliografia}

Saxena S., Orley J. (1997), Quality of life assessement, „The World Health Organization perspective. Eur. Psychiatry" nr 3, 12, s. 263-266.

Schipper H. et al. (1996), Quality of life studies: definitions and conceptual issues, [w:] Quality of Life and Pharmacoeconomics in Clinical Trials, red. B. Spilder, Philadelphia, s. 11-23.

World Health Organization (1993), Report of WHOQOL Focus Group Work, Geneva.

World Health Organization (2013), Multi-country assessment of national capacity to provide hearing care, Geneva, http://www.who.int/pbd/deafness/news/IECD/en/index1.html.

Wyrok z dnia 25 sierpnia 2010 r., sygn. akt VI SA/Wa 853/10, LEX nr 759763. 